\title{
Islamic Religiosity and Its Influence on Muslim Students' Travel Preferences
}

\author{
Sedigheh Moghavvemi* and Ghazali Musa
}

\begin{abstract}
Manuscript type: Research paper

Research aims: This paper aims to examine the relationship between Islamic religiosity and preferences towards Islamic tourism products and services. This paper also compares Islamic tourism product and service preferences between Iranian and Malay university students.

Design/Methodology/Approach: Using the online survey method, this study collects data from 422 Malay and Iranian university students. The collected data are then analysed using structural equation modelling (SEM).

Research findings: The findings indicate that Islamic religiosity plays a significant role in determining Islamic travel preferences. While Malays reported higher levels of Islamic religiosity, the Iranians are more influenced by their religiosity when deciding on travel preferences.

Theoretical contributions/Originality: Despite literature indicating that there is an interaction between religion and tourism, the effect of Islamic attributes on destination choices remains fragmented. Aiming to close this gap, this study examines and compares the influence of Islamic religiosity on Muslim travel preferences by comparing the Malay and Iranian students.

Practitioner/Policy implications: The findings imply that service providers should be mindful of the different levels and influences of Islamic religiosity on Islamic travel preferences when designing tourism products and offering services to both markets.

Research limitation/Implications: This study limits the comparison to only Iranian and Malay students, thereby suggesting that future
\end{abstract}

\footnotetext{
* Corresponding author: Sedigheh Moghavvemi is a Senior Lecturer at the Department of Operations and Management Information Systems, Faculty of Business and Accountancy, University of Malaya, Malaysia. Email: sedigheh@um.edu.my

Ghazali Musa is a Professor at the Department of Business Policy and Strategy, Faculty of Business and Accountancy, University of Malaya, Malaysia. Email: ghazalimz@um.edu.my
}

https://doi.org/10.22452/ajba.vol11no2.10 
research could include more diverse samples of Muslim students including those from non-Muslim countries.

Keywords: Islamic Religiosity, Islamic Beliefs, Islamic Practices, Islamic Travel Preferences, Structural Equation Modelling JEL Classification: M3

\section{Introduction}

Religion and religiosity are two pertinent factors most likely to influence human behaviours (Mokhlis, 2009) and history indicates that religion is one of the most universal and influential social institutions that can assert a considerable amount of influence on the believer's attitude, values and behaviours, both at the individual and the societal level. Religion can also influence one's material life and attitude towards the consumption of goods and services (Shah Alam, Mohd, \& Hisham, 2011). Religion refers to one's devotion to God or a certain faith while religiosity is defined as the degree to which an individual commits to a particular religion (Zamani-Farahani \& Musa, 2012). Religiosity shapes an individual's emotional experience, cognition and psychological wellbeing and that, in turn, affects the consumption choices which the individual makes (Shah Alam et al., 2011).

The importance of religion on tourism has been highlighted by Weidenfield (2005) who views tourism as a religious phenomenon. Tourism is described as a competitor that competes with religion for people's time, virtually. Within the context of tourism, it seems that one's religion may influence the choice of one's destination and product preferences (Weidenfeld \& Ron, 2008).

Many studies (Weidenfeld, 2006; Weidenfeld \& Ron, 2008, ZamaniFarahani \& Musa, 2012; Battour, Battor, \& Bhatti, 2014, Battour, Ismail, Battor, \& Bhatti, 2014) have investigated the interaction between tourism and religion. For instance, Zamani-Farahani and Musa (2012) examined the effect of Islamic religiosity on the social cultural impact of tourism. They reported that the level of Islamic religiosity, which consists of Islamic beliefs and Islamic practices, can influence the perception of the socio-cultural impact of residents of selected small towns in Iran.

While previous studies (Battour et al., 2014; Batson, Schoenrade, \& Ventis, 1993) have established the importance of Islamic religiosity on tourism, the field remains understudied, with little work done to show how Islamic religiosity affect preferred travel destinations. Researchers 
such as Hassan (2005, 2007), Zamani-Farahani and Musa (2012), and Willson (2008) confirmed that the variation in Islamic religiosity in different countries affect the respective attitudes and decision making of the people in their daily lives. These researchers also believed that even though basic Islamic values and practices may be similar, there are differences in the levels of the two constructs of religion and religiosity among believers. These differences may stem from their respective origin of cultural heritage that had existed prior to Islam. This uneven focus invites further attempts to explore this field.

The number of people believing in the Islamic faith is currently increasing (from 1.84 billion in 2007 to 2.08 billion in 2014) and this escalation in number makes it necessary for scholars to conduct studies to examine their travelling needs and requirements since the world has become globalised enough for people to want to travel due to work and leisure (Zailani, Omar, \& Kopong, 2011). Considering that previous travels and holiday destinations seldom take into account what Muslim travellers require, today, it has become quite a challenge for the tourism industry to pay serious attention to the needs of Muslim travellers and in particular, holiday destinations in non-Muslim countries (Battour, Ismail, \& Battor, 2011). It is very likely that some Muslim travellers may decide not to travel to a particular destination which does not offer Islamic attributes that cater to the needs of Muslim travellers. However, when holiday destinations are able to be sensitive to the needs of Muslim tourists, their desire to visit these places increases. Although Islamic attributes are important considerations for Muslims when travelling abroad, efforts to explain the effect of Islamic religiosity on destination choices have remained fragmented.

Motivated by this gap, the current study thus aims to examine how Islamic religiosity influence Muslim student's travel preferences. It also compares the differences in how Islamic religiosity influences the travel preferences of the Malay and Iranian university students who share the same faith in Islam. The current study partially adopts the research instrument of Zamani-Farahani and Musa (2012) to examine Islamic travel preferences. This study specifically selected two Muslim countries comprising Malaysia and Iran where Malaysia represents the Southeast Asian region and Iran represents the Middle East peninsular. While Iranian Muslims are predominantly Shia, Malaysian Malays are predominantly Sunni, making these two groups of Muslims different in terms of denomination. A comparison of these two groups of Muslims and their preferences for travelling preferences would be able to 
provide valuable information that can be used to enhance the Muslim travel markets.

This paper is organised in the following order. Section 2 reviews the literature on Islamic religiosity, Islamic tourism products and services, and the general Islamic knowledge of Malay and Iranian Muslims. Section 3 details the research method employed. Section 4 presents the results and discusses the findings of the study and Section 5 concludes this paper.

\section{Literature Review and Hypotheses Development}

\subsection{Religion and its Influence on Behaviour}

Religion is one of the major elements in the development of human history and civilisation (Vukonic, 1996), and religiosity is acknowledged to be amongst the most important cultural force and the key influence on behaviour (Essoo \& Dibb, 2004). Religion defines the idea for life, which reflects the values and attitudes of societies and individuals. Such values and attitudes shape the behaviour and practices of institutions and the people. In view of the significant influence of religion on people's attitudes, values and behaviour, many studies (Battour et al., 2014; Batson et al., 1993) measured religiosity and its effect on human behaviour. The results of different researches (Weidenfeld \& Ron, 2008; Battour et al., 2014; Batson et al., 1993) showed that religion affects various aspects of human life.

McDaniel and Burnett (1990) asserted that the effect of religious beliefs on behaviour emanates from two main perspectives. First, it sets taboos and obligations on its adherents. Examples include religious rules forbidding Jewish and Muslim believers from consuming pork, or Hindus from consuming beef. Second, it contributes to the formation of the culture, attitude and values in a society (McClain, 1979). This formation, however, also affects those who do not practice any religion, or do not believe in God (Elboim-Dror, 1994). Such influences may be linked to the mundane activities that are absent from the holy books frequently used by religious people as a guide for their daily lives. For example, a body of research has demonstrated the differences in certain value systems based on the individual's religious 'belonging' (Rokeach, 1969; Batson et al., 1993). Here, people perceive religion as a factor that influences their environment, and that such influences are not linked to the individual's level of religious belief. Aspects of life affected by 
such religious 'belongings' could include academic studies (Lehman \& Shriver, 1968) or the perception of actions as good and evil (DeJong, Faulkner, \& Warland, 1976). In their studies, Poria, Butler and Airey (2003) and McDaniel and Burnett (1990) also hinted on how religion affects behaviour through explicit and clear guidelines on acceptable/ unacceptable behaviour or practices. These are then used to shape the culture, attitude and values of a society.

Since religiosity is the degree by which individuals commit to a religious group (Essoo \& Dibb, 2004), religiosity can be measured by using two main dimensions - belief and practice (Batson et al., 1993; Matsuoka, 1997; Zamani-Farahani \& Musa, 2012). Marks and Dollahite (2001) also pointed out that religious beliefs consist of personal and internal beliefs, framings, meanings and perspectives of religion. These may be demonstrated inward by respective individuals or they may be expressed outwardly as observable expressions of faith as exhibited through behaviours such as scripture studies, praying, specific traditional practices and religious rituals. While belief is the first predictor for providing a framework to make sense of one's life (Morgan \& Fastides, 2009), the Religious Orientation Scale introduced by Allport (1950) conceptualises intrinsic and extrinsic religion as the main dimension in measuring religiosity. These two dimensions represent different aspects of motivation for the believer. High intrinsic believers practise religion for its own sake; high extrinsic believers use religion as an avenue to a social or personal end (e.g. comfort, acceptance) (King \& Crowther, 2004).

Most researchers (Battour et al., 2014; Hassan, 2005) agree with the two dimensions of measuring religiosity: religious belief and religious practice. Nonetheless, using the three religiosity dimensions to measure religiosity is also common among some researchers (e.g. Duriez, Fontaine, \& Hutsebaut, 2000; Tan, 2006). Of those researchers who do so, the third dimension was used because it has different elements in the measurement which applies different terminologies such as 'communities' (Marks \& Dollahite, 2001), 'organisations' (Krause, 1993), 'experiences' (Tan, 2006), 'spirituality' (Duriez et al., 2000), 'affects' (Cornwall, Albrecht, Cunningham, \& Pitcher, 1986) and 'experientials' (Caird, 1987).

Following Zamani-Farahani and Musa (2012) and Tiliouine and Belgoumidi (2009), this study aims to measure Islamic religiosity based on the main religious texts of Islam - the Quran and the Hadith (the sayings and actions of the Prophet) which specify the two dimensions of Islamic beliefs and practices. 


\subsection{The Islam of Iranians and Malays}

Islam is one of the world's major religion. It has over a billion followers (Zailani et al., 2011) throughout the world. As a religion, Islam not only emphasises on the acts of worship; it is also a way of life. Willson (2008) pointed out that religion is often influenced by the differing cultures and the respective traditions the believers live in. In that regard, it can be deduced that while two countries can practise the same faith and be Muslims, there are differences in their corresponding behaviours due to their differences in culture. This observation is verified by ZamaniFarahani and Musa (2012) who mentioned that various Islamic nations may have similar religious beliefs but their cultures and the roles of the local community, as well as the level of their governmental intervention, may vary considerably. It is thus apt to mention that the interpretation of Islamic laws across other Muslim nations in the world is not uniform. There are variations among these Muslim countries where their religiosity may vary from being conservative to liberal (Hassan, 2005). Countries such as Malaysia, Oman and Turkey exercise a more relaxed form of Islamic laws (Hashim, Murphy, \& Hashim, 2007) as compared to other countries like Afghanistan, Saudi Arabia and Pakistan.

As a nation, Iran has been very much influenced by the Persian culture that surrounded the country prior to the Islamic civilisation (Zamani-Farahani \& Musa, 2012). Modern Iran not only reflects its Islamic faith and culture but also its long history influenced by ancient Persia (Baum \& O'Gorman, 2010). Observations also indicate that Iranians have a strong attachment to their heritage and culture (ZamaniFarahani \& Musa, 2012), thus Iranians have a higher level of Islamic beliefs but lower levels of Islamic practices. It was also asserted that Iranians with higher Islamic beliefs show greater awareness in the positive socio-cultural impact of tourism (Hassan, 2005). In this regard, Iranians were less likely to express their religiosity.

The Islam practised in Southeast Asia is distinctly different from the Islam practised in the Arabian Peninsula. The former practises a more moderate form of Islam. This form of practice carries a thin veneer of the indigenous and traditional culture of animism and some extent of the earlier influence of Hinduism (Houben, 2003). Hassan (2005) compared the Muslim piety of over 6,000 respondents gathered from Egypt, Indonesia, Iran, Kazakhstan, Malaysia, Pakistan and Turkey. Based on the index of orthodoxy, the findings showed that Malaysia was a more orthodox country, scoring 55 per cent on the index compared to Iran's 
14 per cent. In the ritualistic dimension, the Malays in Malaysia also demonstrated a higher commitment to Islamic rituals when compared to the Iranians (Hassan, 2005).

Religiosity can differ based on geographical locations (Krauss et al., 2006). For instance, Malaysian Muslim youths in rural areas demonstrated a higher level of religiosity when compared to their urban counterparts. This may be due to the fact that young urban Muslims have been exposed to a more diverse cultural milieu, hence they were less influenced by religion and traditional lifestyles (Krauss et al., 2006). Building on this idea, many researchers (Yoon \& Uysal, 2005; Plangmarn, Mujtaba, \& Pirani, 2012) in the field of tourism have argued that travellers from varying cultural backgrounds seek different travel benefits and have different preferences for travel products and services. Therefore, it is expected that Iranian and Malay Muslims who come from different cultural backgrounds would be reporting different travel preferences since they also adhere to different sects of Islam.

There are obvious differences between the two Muslim cultures. Hassan $(2005,2007)$ reported that Malay Muslims scored higher in orthodoxy (55 per cent) compared to Iranian Muslims (14 per cent). In the ritualistic dimension, Malay Muslims also showed higher commitments to Islamic rituals when compared to Iranians (Hassan 2005). Among the Iranians, the score for the Index of Religious commitment in religious beliefs was found to be higher when compared to Islamic practices. They were also less likely to express their Islamic religiosity when compared to other Muslim followers from other countries (e.g. Indonesia, Pakistan, Egypt and Malaysia). Iranians also participated less frequently in religious services than citizens from Indonesia, Pakistan, and Bangladesh. Religion often takes a slant when contrasted with the culture of the area (Willson, 2008).

\subsection{The Relationship between Islamic Religiosity and Islamic Travel Preferences}

Religion and tourism are correlated in terms of consumer (tourist) and supplier (host) behaviour and they seem to have corresponding relationships (Poria, Reichel, \& Brandt, 2010). Literature (Walter, 2001; Hassan, 2005) suggests that religion is a fundamental element of our culture and it is linked to many aspects of our life and behaviour. Religion is one of the most important factors considered by consumers when deciding on their travel/location preferences (Collins \& Tisdell, 2002). Most tourists, 
including Muslims, choose destinations based on what complies with their beliefs (Hamza, Chouhoud, \& Tantawi, 2012). Since Islam provides an extensive framework concerning what is or is not permissible for its followers' daily activities (e.g. food, cosmetics, financial issues, and pharmaceutical products) (Mukhtar \& Butt, 2012), they are expected to follow the Islamic way of living and this adherence influences their decision-making more than any other factors (Shah Alam et al., 2011).

As religion is a pertinent factor in their daily activities including their choice of travel destinations and activity preferences, Muslims often wish to ensure that Islamic religious attributes are available at their travelling destinations (Collins \& Tisdell, 2002). Among the attributes expected are halal food, suitable hotels and suitable airlines (Jibreen, 1996). According to Battour et al. (2011), many Muslim scholars believe that visiting places where sexual permissiveness is rampant is not permissible even for the sake of tourism (Poria et al., 2010). This implies that the destination attraction is a pertinent aspect that may influence the travel decision of Muslim tourists. Although some religious places also represent well-known tourist attractions (Poria et al., 2010), many scholars recognise that such religious places are not only visited for religious purposes but also for distinct reasons such as their architecture, appearance and historical importance, some of which have no association with religion (Poria et al., 2010). Travel preferences are often studied in relation to satisfaction, destination loyalty and travel revisits (Battour, Battor, \& Ismail, 2012) and only a few studies (Battour et al., 2011; Ibrahim, Zahari, Sulaiman, Othman, \& Josoff, 2009) had considered looking at Islamic attributes as factors contributing to travel preferences.

Duman (2011) conducted a study among Turkish Muslims and the results emphasised the value of Islamic tourism by constructing motivational factors from an Islamic perspective. The three identified motivational factors include generic, Islamic, and non-Islamic factors. From the Islamic perspective, Battour et al. (2011), Ibrahim et al. (2009) and Heyer (2008) looked at the preferences of Muslim travellers or religious travel attributes such as Islamic-friendly hotels that meet the religious needs of patrons, halal food and modest dress code. Literature indicates that religion influences the formation of culture, values and attitudes in a society, which, in turn, impacts their decisionmaking including travel and location preferences. Travel intentions and destination choices are attitudes and behaviours influenced by individual beliefs and practices. Given these arguments, this study hypothesised that: 
$\mathrm{H}_{1}$ : There is a positive relationship between Islamic beliefs and Islamic travel preferences.

$\mathrm{H}_{2}$ : There is a positive relationship between Islamic practices and Islamic travel preferences.

Based on the hypotheses formulated, the following conceptual framework was developed (Figure 1).

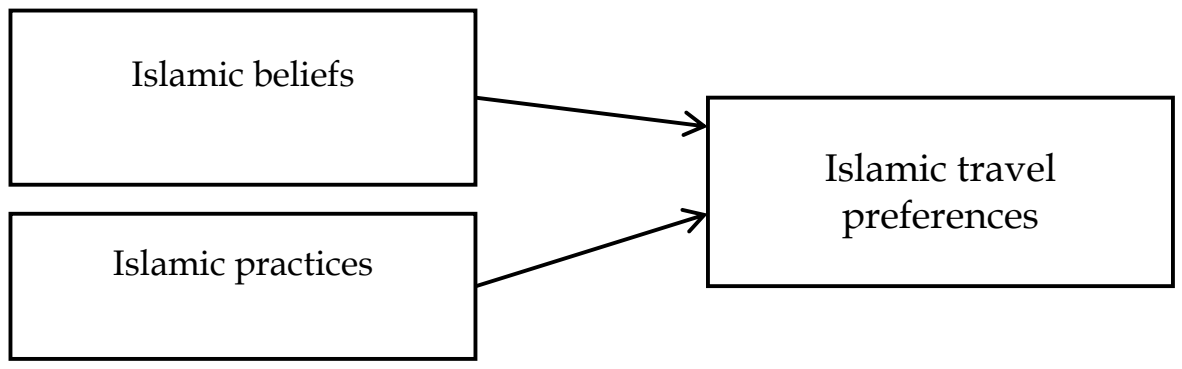

Figure 1: Conceptual Framework

\section{Research Methodology}

\subsection{Measurement}

In this study, Islamic travel preferences was measured by using twentythree items adapted from literature (i.e. Duman, 2011; Battour et al., 2011). These measurements assess the travel preferences of Muslims, in terms of products, services, and entertainment during their holidaytaking. This study also adopted a duo-religiosity dimension consisting of Islamic beliefs (Iman) and Islamic practices (Amal) proposed by previous researchers (i.e. Mokhlis, 2009; Zamani-Farahani \& Musa, 2012). In this study, eighteen items were selected to measure the two dimensions. All the 18 items were measured by using a 7-point Likert scale, ranging from (1) strongly disagree, to (7) strongly agree.

\subsection{Survey Administration and Sampling Method}

This study employed the online survey method using a questionnaire to test the conceptual framework and the formulated hypotheses. A panel consisting of five senior academics from relevant backgrounds was selected to establish the content validity of the research constructs. Subsequently, this study pre-tested the questionnaire with a sample of 
ten students to establish its face validity. A reliability analysis was then performed. The Cronbach's Alpha for the measurement items was found to be greater than 0.70 which is within the recommended value (Cavana, Dalahaye, \& Sekaran, 2001).

The population of this study comprised Malay and Iranian Muslim university students studying in Malaysia. Since Islam is a part of both cultures, the Malay and Iranian students were likely to display some similarities as well as differences in their attitudes and preferences when travelling. This study focussed on university students as subjects, and this is an accepted practice as it has been applied in various disciplines such as marketing, consumer research and social psychology (Kubickova \& Ro, 2011). University students are often considered to be the current and future decision-makers (Meek, 2004) not only for their respective families but also at their workplaces. Thus, they are considered to be better representatives of future tourists who are not only highly educated, naturally curious about the world but will potentially be working for a higher pay. Furthermore, students represent an unattended segment that can increasingly engage in vacation breaks. In this regard, they serve as a potentially lucrative market segment for pleasure travels (Gallarza \& Saura, 2006; Musa, Mohammad, Thirumoorthi, Moghavvemi, \& Kasim, 2015).

Recruiting respondents is not an easy task and recruiting a huge set of respondents is even more challenging. Hassan's (2005) study comprised a large sample of 6,000 respondents who were recruited based on the snowballing approach. For a quantitative study, this sampling technique is considered weak because respondents are likely to be circulated among close friends. In the current study, we purposefully sampled 10 universities, and within these universities, we sampled a certain number of students to ensure a better coverage in population sampling. The respondents were selected from within Malaysia to represent the existing Malay and Iranian Muslim population of Malaysia and Iran. These public and private universities comprise Universiti Malaya (UM), Universiti Putra Malaysia (UPM), Universiti Teknologi Malaysia (UTM), Universiti Kebangsaan Malaysia (UKM), Management and Science University (MSU), Multimedia University (MMU), Universiti Islam Antarabangsa Malaysia (UIAM), Universiti Sains Malaysia (USM), and Universiti Malaysia Sarawak (UNIMAS). The ten universities were specifically selected because they contained the majority of Iranian students studying in Malaysia. From the list of students provided by the universities, we quota-sampled a total of 4,000 
students (400 from each university) to represent the individual ethnic group as well as gender. From each university, 200 Iranian and 200 Malay students were selected and the sample comprise equal sampling of males and females.

Having identified the emails of the students provided by their alma mater, the questionnaires were then sent electronically to their respective e-mails. This was followed by two e-mail reminders within a month. Zikmund, Babin, Carr and Griffin (2013) concurred that an online survey done through the email is a reliable method for collecting data especially if the population of the study can be reached this way. In this study, we used the email survey because all the students registered in the universities have access to an email for communication. A total of 4000 questionnaires were distributed through the email, making this a fast, cheap, and convenient method of administration. At the end of the data collection period, we received 422 completed questionnaires, generating a response rate of 10.6 per cent, of which Iranians and Malays were represented by 235 ( 55.5 per cent) and 187 (44.5 per cent) students, respectively. We received a very large sample size, and the combined use of the purposive and quota sampling approach for data collection ensured that our samples would be representative of the Iranian and Malay students in Malaysia. We also assessed the possibility of nonresponse biases (Malhotra \& Grover, 1998) by comparing the variables between early respondents (a total of 196 who responded within one to three weeks) and late respondents (a total of 226 responded after 3 weeks) (Armstrong \& Overton, 1977). This form of testing for potential non response biases has been adopted in many research disciplines including tourism (e.g., Chau \& Jim, 2002; Karahanna, Straub, \& Chervany, 1999). In this context, we examined the means and standard deviations of all the variables and the results showed that there were no significant differences between early and late respondents. The results indicated that students who responded late to the survey were likely to have similar perceptions of the constructs compared to students who had responded earlier, thereby dismissing the possibility of nonresponse biases.

Of these respondents, 69.1 per cent were females, and 30.9 per cent were males (see Table 1). Majority of the respondents defined themselves as moderately religious (72.7 per cent), followed by those who defined themselves as very religious (16.6 per cent), and those who defined themselves as not religious ( 9.5 per cent). More than half or 50.6 per cent of the respondents were between 25 and 35 years old, followed by 24.4 
Table 1: Participant Characteristics

\begin{tabular}{llcr}
\hline Characteristic & Group & Frequency & Percentage \\
\hline Gender & Female & 291 & 69.1 \\
& Male & 131 & 30.9 \\
Marital status & Single & 307 & 72.8 \\
& Married & 115 & 27.3 \\
Age & Below 25 & 103 & 24.4 \\
& 25-35 & 214 & 50.6 \\
& $36-45$ & 80 & 19.0 \\
Level of religiosity & Over 45 & 25 & 6.0 \\
& Not religious & 40 & 9.5 \\
& Moderately religious & 307 & 72.7 \\
& Very religious & 70 & 16.6 \\
\hline
\end{tabular}

Note: $\mathrm{n}=422$.

per cent who were below 25 years and 19 per cent who were between 36 and 45 years old. The number of students above the age of 45 was six per cent. In terms of their marital status, 72.8 per cent were single and 27.3 per cent were married.

\section{Data Analysis and Findings}

\subsection{Exploratory Factor Analysis}

Prior to the structural model analysis, this study had conducted an exploratory analysis to ensure that all the measurements used were valid and reliable and also to verify the components of the proposed conceptual framework. We ran an exploratory factor analysis with principal component analysis and oblique rotation. The analyses showed that the Keiser-Meyer-Olkin (KMO) measure of sampling adequacy test was 0.818 , and the Bartlett's test of sphericity was significant, indicating that the data were acceptable for factor analysis. All the items loading achieved the recommended value of 0.5 . The factor loading revealed that the items related to religiosity loaded highly in their predefined construct (beliefs and practice), however, the items differed from the conceptual framework proposed earlier. The items measuring Islamic travel preferences were loaded on three dimensions called Islamic 
service travel preferences (ISTP), Islamic product travel preferences (IPTP), and Hedonic avoidance travel preferences (HATP) (All the items and factor loadings and reliability of each construct are presented in Appendix 1). Islamic service travel preferences (ISTP) was concerned with religious preferences such as halal food, transportation services and Islamic services at hotels and tourism sites. Islamic product travel preferences (IPTP) was concerned with preferences for tourism sites with Islamic history, architecture, entertainment, and business and medical treatment. Hedonic avoidance travel preferences (HATP) was concerned with preferences to avoid hedonistic activities such as gambling, nightlife, drinking alcohol and other non-Islamic activities.

In this study, the respondents were divided into two groups Iranians and Malays so as to examine the levels of Islamic religiosity and Islamic travel preferences. The Malay students scored higher in Islamic religiosity (Islamic beliefs $(m e a n=4.63)$ and Islamic practice $($ mean $=4.56)$ ) while the Iranian students were lower in religiosity (Islamic beliefs $($ mean $=3.70)$ and Islamic practice $(m e a n=3.74))$. The Malays also scored higher means in the dimensions of the Islamic travel preference construct: Islamic service travel preferences (Malay mean=3.70, Iranian mean $=2.93$ ) and Islamic product travel preferences (Malay mean $=4.08$, Iranian mean=2.99), and hedonic avoidance travel preferences (Malay mean $=4.12$, Iranian mean=3.54).

Based on the exploratory factor analysis results, the hypotheses and conceptual framework developed initially was revised (see Figure 2). To confirm the new model, we conducted a confirmatory factor analysis based on the results of the exploratory factor analysis.

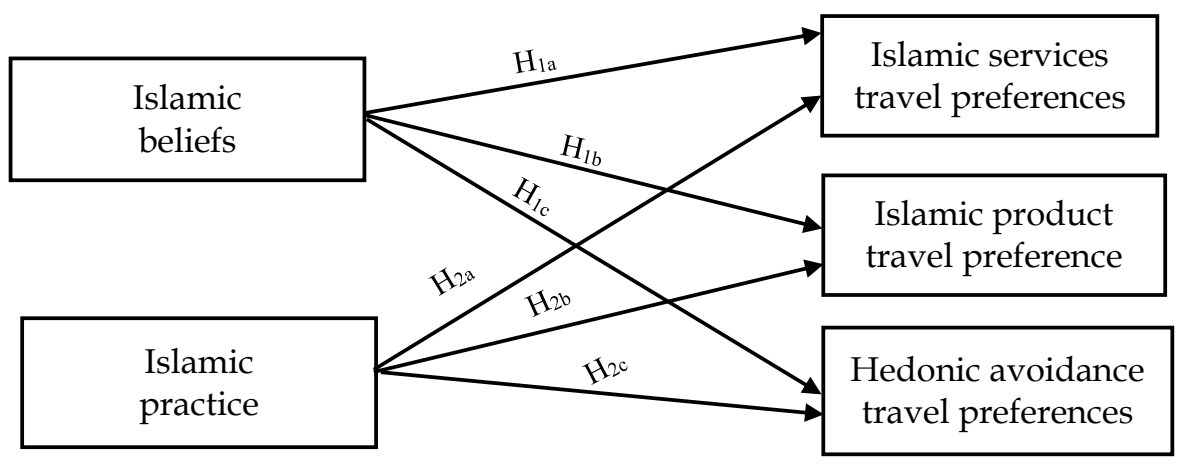

Figure 2: Muslim Travel Preferences 


\subsection{Confirmatory Factor Analysis}

The Confirmatory Factor Analysis was conducted using the AMOS application. Multiple goodness-of-fit indices which include Chi-square $\left(\chi^{2}\right), x^{2} / d f$, Comparative Fit Index (CFI), Root Mean Square Error of Approximation (RMSEA), Tucker Lewis Index (TLI), and goodness of fit (GFI) were used to determine the model's fitness. All the fit indices $\left(X^{2} /\right.$ $\mathrm{df}=2.69, \mathrm{CFI}=0.954, \mathrm{RMSEA}=0.064, \mathrm{TLI}=0.947, \mathrm{GFI}=0.874$ ) realised the recommended value (Hair, Bush, \& Ortinau, 2006).

Apart from the indices, this study also carried out various validity and reliability tests on the measurement model. All of the constructs reported composite reliability of above 0.8 , with the Average Variance Extracted (AVE) being above 0.6. Moreover, all of the factor loadings of the items were above 0.7 , and were significant at $p<0.001$. These results indicated that the model satisfied the convergent validity. Based on the Fornell and Lacker's (1981) approach, this study tested the discriminant validity on the measurement model (Table 2). All of the constructs had a substantially higher AVE value compared to their correlation with other constructs, proving there is discriminant validity.

Table 2: Discriminant Validity

\begin{tabular}{llllll}
\hline Constructs & ISTP & ISP & HAP & IB & IP \\
\hline $\begin{array}{l}\text { Islamic service travel } \\
\text { preferences (ISTP) }\end{array}$ & $\mathbf{0 . 8 1 0}$ & & & & \\
$\begin{array}{c}\text { Islamic product travel } \\
\text { preferences (ISTP) }\end{array}$ & $0.673^{* *}$ & $\mathbf{0 . 7 8 2}$ & & & \\
$\begin{array}{c}\text { Hedonic avoidance travel } \\
\text { preferences (HATP) }\end{array}$ & $0.491^{* *}$ & $0.413^{* *}$ & $\mathbf{0 . 7 8 3}$ & & \\
$\begin{array}{l}\text { Islamic beliefs (IB) } \\
\text { Islamic practices (IP) }\end{array}$ & $0.681^{* *}$ & $0.701^{* *}$ & $0.517^{* *}$ & $\mathbf{0 . 8 3 1}$ & \\
\hline
\end{tabular}

Note: Value on diagonal are square root of AVE; $\mathrm{CR}=$ Composite reliability; $\mathrm{AVE}=$ Average variance extracted; ${ }^{* *} \mathrm{p}<.01$.

\subsection{Structural Model Analysis}

Following the Confirmatory Factor Analysis, we conducted the structural model analysis. Similar multiple goodness-of-fit indices were used to evaluate the measurement model employed. As indicated in Table 3, 
Table 3: Hypothesis Testing on Travel Preferences

\begin{tabular}{lcccccc}
\hline Constructs & $\begin{array}{c}\text { Hypo- } \\
\text { thesis }\end{array}$ & $\beta$ & S.E. & C.R. & P & $\begin{array}{c}\text { Sup- } \\
\text { ported }\end{array}$ \\
\hline Islamic beliefs $\rightarrow$ ISTP & $\mathrm{H}_{1 \mathrm{a}}$ & 0.466 & 0.119 & 5.080 & $0.000^{* *}$ & Yes \\
Islamic beliefs $\rightarrow$ IPTP & $\mathrm{H}_{1 \mathrm{~b}}$ & 0.285 & 0.123 & 2.569 & $0.010^{* *}$ & Yes \\
Islamic beliefs $\rightarrow$ HATP & $\mathrm{H}_{1 \mathrm{c}}$ & 0.271 & 0.208 & 2.064 & $0.041^{*}$ & Yes \\
Islamic practices $\rightarrow$ ISTP & $\mathrm{H}_{2 \mathrm{a}}$ & 0.409 & 0.090 & 4.446 & $0.000^{* *}$ & Yes \\
Islamic practices $\rightarrow$ IPTP & $\mathrm{H}_{2 \mathrm{~b}}$ & 0.462 & 0.095 & 4.071 & $0.000^{* *}$ & Yes \\
Islamic practices $\rightarrow$ HATP & $\mathrm{H}_{2 \mathrm{c}}$ & 0.283 & 0.158 & 2.107 & $0.035^{* *}$ & Yes \\
\hline
\end{tabular}

Structural Model Fit Indices: $\chi^{2} / \mathrm{df}=3.14 ; \mathrm{TLI}=0.934 ; \mathrm{CFI}=0.943 ; \mathrm{IFI}=0.943$; RMSEA $=0.079 ;$ GFI $=0.859$.

Note: $\beta=$ Standardized Regression Weight; S.E. $=$ Standardized Error; C.R. $=$ Critical Ratio; ${ }^{*} \mathrm{p}<0.05 ;{ }^{* *} \mathrm{p}<0.01$

all of the fit indices achieved the cut-off points, indicating that the model fit the data well. Overall, the model was able to explain 79 per cent of the variance in Islamic travel preferences (ISTP), 66 per cent of the variance in Islamic product travel preferences (IPTP), and 30 per cent of the variance in hedonic avoidance travel preferences (HATP).

The results of the structural model were also used to test the hypotheses. The findings indicated that the relationships between Islamic beliefs with Islamic service travel preferences (ISTP), Islamic product travel preferences (IPTP), and hedonic avoidance travel preferences (HATP) were positive and significant, thereby supporting $\mathrm{H}_{1 \mathrm{a}}, \mathrm{H}_{1 \mathrm{~b}}$ and $\mathrm{H}_{1 \mathrm{c}}$. Similarly, the findings also indicated that all the hypothesised paths from the Islamic practices had ISTP $(\beta=0.409$, $\mathrm{p}<0.001)$, IPTP $(\beta=0.462, \mathrm{p}<0.001)$ and HATP $(\beta=0.283, \mathrm{p}<0.05)$ which were positive and significant, thus supporting hypothesis $\mathrm{H}_{2 a}$, hypothesis $\mathrm{H}_{2 \mathrm{~b}}$ and hypothesis $\mathrm{H}_{2 \mathrm{c}}$ (see Table 3).

We then used a multi-group analysis method to examine the differences between the Malay and Iranian Muslim students. For this purpose, the samples were divided into two groups (Iranians and Malays), and two separate models were run (Hair et al., 2006). The Chi Square differences (constrained and unconstrained path) between the main model and the two groups were significant, proving the moderating effects (Table 4 ) of the variables. 
Table 4: Path Coefficents for Iranian and Malaysian Samples

\begin{tabular}{llc}
\hline Constructs & \multicolumn{2}{c}{$\beta$} \\
\cline { 2 - 3 } & Iranian & Malaysian \\
\hline Islamic beliefs $\rightarrow$ ISTP & $0.463^{* * *}$ & $0.520^{* * *}$ \\
Islamic beliefs $\rightarrow$ IPTP & $0.360^{* *}$ & 0.292 \\
Islamic beliefs $\rightarrow$ HATP & 0.264 & 0.329 \\
Islamic practices $\rightarrow$ ISTP & $0.409^{* * *}$ & 0.139 \\
Islamic practices $\rightarrow$ IPTP & $0.353^{* *}$ & 0.214 \\
Islamic practices $\rightarrow$ HATP & $0.325^{*}$ & 0.011 \\
\hline
\end{tabular}

Note: ${ }^{*} \mathrm{p}<0.05 ;{ }^{* *} \mathrm{p}<0.01 ;{ }^{* * *} \mathrm{p}<0.001$.

The results reported by the two samples differed from the total sample. The relationship between Islamic beliefs and ISTP was significant for the Malay and Iranian students. However, the relationships between Islamic beliefs and IPTP and HATP were not significant for the Malay students. In addition, the results did not show any significant relationship between Islamic practices and ISTP, IPTP or HATP among the Malay students. However, the results showed a significant relationship between Islamic beliefs and ISTP and IPTP for the Iranian students although they were not significant with HATP. The relationship between the Islamic practices and ISTP, IPTP and HATP were all significant for the Iranian students.

\section{Discussion}

This study confirms the presence of the two Islamic religiosity dimensions - Islamic beliefs and Islamic practices - as highlighted in prior works (Mokhlis, 2009; Zamani-Farahani \& Musa, 2012). However, the findings of this study differed from previous studies (see Duman, 2011 and Battour et al., 2011) to some extent. Our results revealed three distinct factors of Islamic travel preferences which include Islamic service travel preferences (ISTP), Islamic product travel preferences (IPTP) and hedonic avoidance travel preferences (HATP).

Our findings validated Hassan's (2005) claim which stated that Malay Muslims were more orthodox in their Islamic piety compared to Iranian Muslims. The findings further indicated that Malay Muslims not only scored higher in Islamic religiosity but also in their Islamic travel 
preferences. The difference between the two groups was expected. As explained by Willson (2008) and Zamani-Farahani and Musa (2012), the two groups came from two different cultural backgrounds. The difference in their cultural backgrounds may have influenced their different levels of religious convictions as evidenced by the different levels in Islamic religiosity and Islamic travel preference. Iranians, who were predominantly Shia Muslims were also possibly influenced by Zoroastrianism, which pre-dated Islam (Zamani-Farahani \& Musa, 2012; Baum \& O'Gorman, 2010). The Malays, on the other hand, practised Islam that has been influenced, to some extent by other indigenous traditional culture of animism and the earlier influence of Hinduism as claimed by Houben (2003).

Using structural equation modelling, we examined the relationships between Islamic religiosity and Islamic travel preferences. The findings indicated that Islamic religiosity has a significant effect on Islamic product travel preferences, hedonic avoidance travel preferences and Islamic service travel preferences. This result, however, was found to be different when the samples were analysed separately. When placed into two separate groups and examined for the constructs' relationships, the results were somewhat different. For both the Malay and Iranian groups, the strongest relationship recorded was between Islamic beliefs and Islamic service travel preferences. This supports an earlier study done by Zamani-Farahani and Musa (2012) who had likewise discovered the dominance of Islamic beliefs in influencing the perception of the sociocultural impact of tourism in Iran. Morgan and Fastides (2009) had also claimed that belief is the first predictor because it provides a framework for which an individual makes sense of his/her life.

For the Malays, the only significant relationship noted was between Islamic beliefs and Islamic service travel preferences while the other five hypothesised relationships were not significant. These results create new insights into the Malay Muslim students' behaviour and the relationship that exists between their beliefs and practices towards their travel preferences. It is suggested that the main concern for Malay Muslims during their holidays is the existence of Islamic services (e.g., accommodation, transportation and entertainment). Other aspects such as Islamic products and hedonistic behaviours were insignificantly influenced by either their beliefs or practices. It is possible that Malay university students in Malaysia take for granted, the presence of Islamic attributes when they travel, especially within the country. This is because they expect Islamic products and services to be available 
everywhere in Malaysia. On the contrary, with exception to hedonistic avoidance, Islamic religiosity was found to play a significant role among the Iranians and its influence on other Islamic travel preferences factors. The predominantly significant hypothesised relationships reflected the reality that despite the relatively lower levels of Islamic religiosity and Islamic travel preferences (compared to the Malays), the religiosity of the Iranian university students seemed to significantly influence their Islamic travel preferences. Perhaps being away from Iran and being in a rather different Islamic cultural environment, Iranians were more careful in making sure that their preferences and activities were in accordance with their beliefs and practices.

It is also interesting to note that Islamic beliefs do not influence the hedonic travel preferences of both the Malay and Iranian students. This study, however, found that unlike the Malays, the Iranians' desire for hedonic travel avoidance was affected by their Islamic practice. The insignificant effect of Islamic religiosity on hedonic travel avoidance among the Malays respondents may reflect a current shift among Muslim students in that their Islamic religiosity does not provide a significant deterrence from performing hedonistic behaviour. Perhaps the city life rampantly experienced by the Malay students (Krauss et al., 2006) and their exposure to different cultures and ethnicities at the same time had produced a set of relatively more open-minded students.

\section{Theoretical and Practical Implications}

The findings of this study have implications on both theory and practice. In the context of Islamic tourism, this study has expanded on prior works done by Duman (2011) and Battour et al. (2011) by further categorising Islamic travel preference into three different dimensional constructs - Islamic service travel preferences (ISTP), Islamic product travel preferences (IPTP) and hedonic avoidance travel preferences (HATP) which focused more on measuring specific needs and preferences. The empirical results generated from this study also indicated that the study has a good explanatory power in determining the three-dimensional Islamic travel preferences. The study has also improved our understanding by uncovering the existence of differences in the factors that could affect Islamic travel preferences, which showed that it could have originated from a distinct culture and behaviour.

In terms of contribution to practices, this study proves that Malay students prefer the presence of Islamic services and hedonic avoidance 
travel preferences while Iranian students were more concerned with the existence of the Islamic product in the destination. Therefore, both the service providers and marketers of tourism could use this information to enhance their market segmentation and their product and service development for Muslim travellers. This study has increased our knowledge on the specific needs of Muslims and their preferences in three main categories, namely product, service and entertainment. In managing tourist destinations, managers should be aware of Muslim preferences and develop the related facilities to satisfy their needs which are related to accommodation, food, transportation, attraction and activities. From a managerial perspective, such an understanding can alert the travel agency to seek opportunities in integrating Muslim preferences and expectations into their marketing plans and products and services. Findings from this study suggest that managers and marketers need to recognise the different sets of service and products targeted for different market segments when developing a strategy to attract Muslim tourists. In order to tap into the Muslim market, they should not ignore the influence of different religiosity and beliefs on value creations, which may be affected by culture. The results of this study provide valuable knowledge on the travel preferences of Muslims and this can be used to enhance or improve the tourism industry.

\section{Research Limitations and Future Research}

Despite the fact that this study provides the opportunity for marketers and service operators to reflect on their products and services offered, it has its limitations. The main limitation of this study is the fact that the sampling process was carried out in Malaysia for both the Malay and Iranian respondents. It is possible that the sampling location may have contributed to the significant relationships noted in the hypothesised model among the Iranian samples since they were overseas Iranians who tend to be more careful in their travel preferences. However, since religion is a part of the culture formed over many generations, it is likely that the Iranian students in Malaysia would display similar attitudes and preferences as those students in Iran. Another possible explanation is that Iranian students who study abroad are away from home and they too could have been affected by other cultures of the host country. Future studies may need to confirm the results of this study by collecting more data from the Iranian students who are based in Iran. Another limitation of this study is that the study was only conducted 
on university students, which could have restrained the generalisability of the findings. The samples may not accurately reflect the true samples of the Malays or the Iranians. It is possible that the general public may have different levels of Islamic religiosity and Islamic travel preferences. Nonetheless, as pointed out earlier, university students represent the future decision-makers and travellers, and they were more likely to be more successful financially. Thus, they would have a higher propensity to travel. Future research can apply this framework to study different religions, especially the differences between the Iranians (who live in Iran) and Malay Muslims.

In conclusion, this study has determined the impact of the Islamic religiosity on Islamic travel preferences among the Malay and Iranian students. It has also provided firm evidence showing the heterogeneous nature in the scores of the research constructs and their corresponding relationships. Marketers and managers may need to be mindful of these differences while developing their marketing and tourism product and services to cater to the increasing interest of Islamic tourism.

\section{References}

Allport, G.W. (1950). The individual and his religion: A psychological interpretation. New York, NY: Macmillan.

Armstrong, J.S., \& Overton, T.S. (1977). Estimating non response bias in mail surveys. Journal of Marketing Research, 14(3), 396-402.

Batson, C.D., Schoenrade, P., \& Ventis, W.L. (1993). Religion and the individual: A social-psychological perspective. New York, NY: Oxford University Press.

Battour, M., Ismail, M.N., \& Battor, M. (2011). The impact of destination attributes on Muslim tourist's choice. International Journal of Tourism Research, 13(6), 527-540. http://dx.doi.org/10.1002/jtr.824

Battour, M.M., Battor, M.M., \& Ismail, M.N. (2012). The mediating role of tourist satisfaction: A study of Muslim tourists in Malaysia. Journal of Travel \& Tourism Marketing, 29(3), 279-297. http://dx.doi.org/10.1080/10 548408.2012.666174

Battour, M.M., Battor, M.M., \& Bhatti, M.A. (2014). Islamic attributes of destination: Construct development and measurement validation, and their impact on tourist satisfaction, International Journal of Tourism Research, 16(6), 556-564. http://dx.doi.org/10.1002/jtr.1947

Battour, M.M., Ismail, M.N., Battor, M.M., \& Awais, M. (2014). Islamic tourism: An empirical examination of travel motivation and satisfaction in Malaysia. Current Issues in Tourism, 20(1), 50-67. http:/ / dx.doi.org/10.1080 /13683500.2014.965665 
Baum, T., \& O'Gorman, K.D. (2010). Iran or Persia: What is in a name, the decline, and fall of a tourism industry? In R. Butler \& W. Suntikul (Eds.), Tourism and political change (pp. 175-185). Oxford: Goodfellow Publishers.

Caird, D. (1987). Religiosity and personality: Are mystic introverted, neurotic, or psychotic? British Journal of Social Psychology, 26(4), 345-346. http:// dx.doi.org/10.1111/j.2044-8309.1987.tb00798.x

Cavana, B., Dalahaye, B., \& Sekaran, U. (2001). Applied business research: Qualitative and quantitative methods. Brisbane, Australia: John Wiley \& Sons.

Chau, P.Y.K., \& Jim, C.C.F. (2002). Adoption of electronic data interchange in small and medium sized enterprise. Journal of Global Information Management, 10(4), 61-85.

Collins, D., \& Tisdell, C. (2002). Gender and differences in travel life cycles. Journal of Travel Research, 41(2), 133-143. http://dx.doi.org/10.1177/ 004728702237413

Cornwall, M., Albrecht, S.L., Cunningham, P.H., \& Pitcher, B.L. (1986). The dimensions of religiosity: A conceptual model with an empirical test. Review of Religious Research, 27(3), 226-244. http://dx.doi.org/10.2307/ 3511418

DeJong, G.F, Faulkner, J.E., \& Warland, R.H. (1976). Dimension of religiosity reconsidered: Evidence from a cross-cultural study. Social Forces, 54(4), 866-889. http://dx.doi.org/ 10.2307/2576180

Duman, T. (2011). Value of Islamic tourism offering: Perspectives from the Turkish experience. Paper presented at the World Islamic Tourism Forum, 12-13 July, Kuala Lumpur, Malaysia. Retrieved from https://www.researchgate.net/ publication/266285126_Value_of_Islamic_Tourism_Offering_Perspectives_ from_the_Turkish_Experience

Duriez, B., Fontaine, J.R., \& Hutsebaut, D. (2000). A further elaboration of the Post-Critical Belief scale: Evidence for the existence of four different approaches to religion in Flanders-Belgium. Psychologica Belgica, 40(3), 153-181.

Elboim-Dror, R. (1994). Gender in utopianism: The Zionist case. History Workshop Journal, 37(1), 99-116. http://dx.doi.org/10.1093/hwj/37.1.99

Essoo, N., \& Dibb, S. (2004). Religious influences on shopping behaviour: An exploratory study. Journal of Marketing Management, 20(7-8), 683-712. http://dx.doi.org/10.1362/0267257041838728

Fornell, C., \& Larcker, D.F. (1981). Evaluating structural equation models with unobservable variables and measurement error. Journal of Marketing Research, 18(1), 39-50. http://dx.doi.org/10.2307/3151312

Gallarza, M.G. \& Saura, I.G. (2006). Value dimensions, perceived value, satisfaction and loyalty: An investigation of university students' travel behaviour. Tourism Management, 27(3), 437-452. http://dx.doi.org/10.1016/j.tourman. 2004.12.002

Hair, J.F., Bush, R.P., \& Ortinau, D.J. (2006). Marketing research. New York: McGraw-Hill Irwin. 
Hamza, I.M., Chouhoud, R., \& Tantawi, P. (2012). Islamic tourism: Exploring perceptions and possibilities in Egypt. African Journal of Business and Economic Research, 7(1\&2), 86-99.

Hashim, N.H., Murphy, J., \& Hashim, N.M. (2007). Islam and online imagery on Malaysian tourist destination websites. Journal of Computer-Mediated Communication, 12(3), 1082-1102. http://dx.doi.org/10.1111/j.1083-6101. 2007.00364.x

Hassan, R. (2005). The state and religious institutions in Muslim societies (RSIS Working Paper, No. 79). Singapore: Nanyang Technological University.

Hassan, R. (2007). On being religious: Patterns of religious commitment in Muslim societies. The Muslim World, 97(3), 437-478. http://dx.doi.org/ 10.1111/j.1478-1913.2007.00190.x

Heyer, H. (2008, July 2). Sharia-compliant hotels: The next big thing in Arabia. eTurboNews. Retrieved from http://www.eturbonews.com/3506/shariacomplianthotels-next-big-thing-arabia

Houben, V.J. (2003). Southeast Asia and Islam. The ANNALS of the American Academy of Political and Social Science, 588(1), 149-170. http://dx.doi. org/10.1177/0002716203588001010

Ibrahim, Z., Zahari, M.S., Sulaiman M., Othman Z., \& Josoff, K. (2009). Travelling pattern and preferences of the Arab tourists in Malaysian hotels. International Journal of Business and Management, 4(7), 3-9.

Jibreen, S.I. (1996). Islamic Fatawa regarding women. Brunei: Darussalam Publishers and Distributors.

Karahanna, E., Straub, D.W., \& Chervany, N.L. (1999). Information technology adoption across time: A cross-sectional comparison of pre-adoption and post-adoption beliefs. MIS Quarterly, 23(2), 183-213. http://dx.doi. org/10.2307/249751

King, J.E., \& Crowther, M.R. (2004). The measurement of religiosity and spirituality: Examples and issues from psychology. Journal of Organizational Change Management, 17(1), 83-101. http://dx.doi.org/10.1108/ 09534810410511314

Krause, N. (1993). Measuring religiosity in later life. Research on Aging, 15(2), 170-197. http://dx.doi.org/10.1177/0164027593152003

Krauss, S.E., Hamzah, A.H., Suandi, T., Noah, S.M., Juhari, R., \& Manap, J.H. (2006). Exploring regional differences in religiosity among Muslim youth in Malaysia. Review of Religious Research, 47(3), 238-252.

Kubickova, M., \& Ro, H. (2011). Are student's real people? The use of student subjects in hospitality research. Paper presented at the 16th Graduate Students Research Conference, University of Massachusetts Amherst. Retrieved from http://scholarworks.umass.edu/gradconf_ hospitality/2011/Poster/87/

Lehman Jr, E.C., \& Shriver Jr, D.W. (1968). Academic discipline as predictive of faculty religiosity. Social Forces, 47(2), 171-182. http://dx.doi.org/ $10.1093 / \mathrm{sf} / 47.2 .171$ 
Malhotra, M.K., \& Grover, V. (1998). An assessment of survey research in POM: From constructs to theory. Journal of Operations Management, 16(4), 407-425. http://dx.doi.org/10.1016/S0272-6963(98)00021-7

Marks, L.D., \& Dollahite, D.C. (2001). Religion, relationships, and responsible fathering in Latter-day Saint families of children with special needs. Journal of Social and Personal Relationships, 18(5), 625-650. http://dx.doi. org/10.1177/0265407501185004

Matsuoka, J.K. (1997). Economic change and mental health on Lana'i: A longitudinal analysis (Report to the National Institute of Mental Health). Manoa: School of Social Work, University of Hawaii. Retrieved from http://www.wsu. edu:8080/wamerstu/ce/conf/habel.html

McClain, E.W. (1979). Religious orientation the key to psychodynamic differences between feminists and non-feminists. Journal for the Scientific Study of Religion, 18(1), 40-45. http:// dx.doi.org/10.2307/1385376

McDaniel, S.W., \& Burnett, J.J. (1990). Consumer religiosity and retail store evaluative criteria. Journal of the Academy of Marketing Science, 18(2), 101112. http:/ / dx.doi.org/10.1177/009207039001800201

Meek, M.D. (2004). Antecedents to the entrepreneurial decision: An empirical analysis of three predictive models (Doctoral thesis, Leeds School of Business, University of Colorado Boulder, Boulder). Retrieved from www. kauffman.org/kdfp

Mokhlis, S. (2009). Relevancy and measurement of religiosity in consumer behavior research. International Business Research, 2(3), 75-84.

Morgan, J., \& Fastides, T. (2009). Measuring meaning in life. Journal of Happiness Studies, 10(2), 197-214. http://dx.doi.org/10.1007/s10902-007-9075-0

Mukhtar, A., \& Butt, M.M. (2012). Intention to choose halal products: The role of religiosity. Journal of Islamic Marketing, 3(2), 108-120. http://dx.doi. org/10.1108/17590831211232519

Musa, G., Mohammad, I., Thirumoorthi, T., Moghavvemi, S., \& Kasim, A. (2015). Exploring visitors' experience using strategic experiential modules (SEMs): The case of Zoo Negara, Kuala Lumpur. International Journal of Tourism Cities, 1(3), 234-253. http://dx.doi/full/10.1108/IJTC-08-20140012

Plangmarn, A., Mujtaba, B.G., \& Pirani, M. (2012). Value and travel motivation of European tourists. Journal of Applied Business Research, 28(6), 1295-1304. http://dx.doi.org/10.19030/jabr.v28i6.7344

Poria, Y., Butler, R.W., \& Airey, D. (2003). Tourism, religion and religiosity: A holy mess. Current Issues in Tourism, 6(4), 340-363. http://dx.doi.org/ 10.1080/13683500308667960

Poria, Y., Reichel, A., \& Brandt, Y. (2010). People with disabilities flight experiences: An exploratory study. Journal of Travel Research, 49(2), 216-227. http://dx.doi.org/abs/10.1177/0047287509336477

Rokeach, M. (1969). Part I. Value systems in religion. Review of Religious Research, 11(1), 3-23. http:/ / dx.doi.org/10.2307/3510550 
Shah Alam, S.S., Mohd, R., \& Hisham, B. (2011). Is religiosity an important determinant on Muslim consumer behaviour in Malaysia? Journal of Islamic Marketing, 2(1), 83-96. http://dx.doi.org/10.1108/17590831111115268

Tan, J.H.W. (2006). Religion and social preferences: An experimental study. Economics Letters, 90(1), 60-67. http://dx.doi.org/10.1016/j.econlet.2005.07.006

Tiliouine, H., \& Belgoumidi, A. (2009). An exploratory study of religiosity, meaning in life and subjective wellbeing in Muslim students from Algeria. Applied Research in Quality of Life, 4(1), 109-127. http://dx.doi. org/10.1007/s11482-009-9076-8

Vukonić, B. (1996). Tourism and religion. New York: Pergamon Press.

Walter, T. (2001). From cathedral to supermarket: Mourning, silence and solidarity. The Sociological Review, 49(4), 494-511. http://dx.doi.org/10.1111/ 1467-954X.00344

Weidenfeld, A. (2006). Religious needs in the hospitality industry. Tourism and Hospitality Research, 6(2), 143-159. http://dx.doi.org/10.1057/palgrave. thr.6040052

Weidenfeld, A., \& Ron, A.S. (2008). Religious needs in the tourism industry. Anatolia: An International Journal of Tourism and Hospitality Research, 19(2), 357-361. http://dx.doi.org/10.1080/13032917.2008.9687080

Willson, G. (2008). Conceptualizing spirituality in the context of tourism. In Proceedings of the 2nd International Colloquium on Tourism and Leisure (ICTL) (p. 53), Chiang Mai, Thailand.

Yoon, Y., \& Uysal, M. (2005). An examination of the effects of motivation and satisfaction on destination loyalty: A structural model. Tourism Management, 26(1), 45-56. http://dx.doi.org/10.1016/j.tourman.2003.08.016

Zailani, S., Omar, A., \& Kopong, S. (2011). An exploratory study on the factors influence the non-compliance to halal among hoteliers in Malaysia. International Business Management, 5(1), 1-12. http://dx.doi.org/10.3923/ ibm.2011.1.12

Zamani-Farahani, H., \& Musa, G. (2012). The relationship between Islamic religiosity and resident's perceptions of socio-cultural impacts of tourism in Iran: Case studies of Sarein and Masooleh. Tourism Management, 33(4), 802-814. http://dx.doi.org/10.1016/j.tourman.2011.09.003

Zikmund, W.G., Babin, B.J., Carr, J.C., \& Griffin, M. (2013). Business research methods (9th ed.). Cincinnati, OH: Erin Joyner. 
Appendix 1: Exploratory Factor Analysis and Reliability Test

\begin{tabular}{|c|c|c|c|}
\hline Factors & Source & $\begin{array}{l}\text { Factor } \\
\text { loading }\end{array}$ & $\begin{array}{l}\text { Cronbach's } \\
\text { Alpha } \alpha\end{array}$ \\
\hline Islamic Service Travel Preferences & & & 0.918 \\
\hline I prefer not to travel during Ramadan & & 0.539 & \\
\hline $\begin{array}{l}\text { I only eat in restaurants with halal } \\
\text { certificate }\end{array}$ & & 0.556 & \\
\hline $\begin{array}{l}\text { I prefer to fly with airlines which provide } \\
\text { praying opportunity on board }\end{array}$ & & 0.701 & \\
\hline $\begin{array}{l}\text { I prefer to use public transportation with } \\
\text { separate areas for men and women }\end{array}$ & & 0.765 & \\
\hline $\begin{array}{l}\text { I prefer to choose hotels with separate } \\
\text { sport facilities for men and women }\end{array}$ & & 0.832 & \\
\hline $\begin{array}{l}\text { I prefer to visit countries which have } \\
\text { more freedom to practice religion }\end{array}$ & & 0.603 & \\
\hline $\begin{array}{l}\text { I do not like to travel in the company of } \\
\text { people who drink alcohol }\end{array}$ & & 0.554 & \\
\hline $\begin{array}{l}\text { I only choose a travel package that } \\
\text { provides halal entertainment }\end{array}$ & & 0.700 & \\
\hline $\begin{array}{l}\text { I prefer to stay in hotels which do not } \\
\text { serve non-halal food }\end{array}$ & & 0.500 & \\
\hline $\begin{array}{l}\text { I prefer to stay in a hotel which provides } \\
\text { praying facilities }\end{array}$ & Duman, 2011; & 0.631 & \\
\hline $\begin{array}{l}\text { I do not like to go to beaches which allow } \\
\text { mixed gender }\end{array}$ & $\begin{array}{l}\text { Battour et al., } \\
2011\end{array}$ & 0.517 & \\
\hline Islamic Product Travel Preferences & & & 0.934 \\
\hline $\begin{array}{l}\text { I prefer to study in Islamic countries } \\
\text { rather than non-Islamic countries }\end{array}$ & & 0.622 & \\
\hline $\begin{array}{l}\text { I prefer to stay in hotels with Islamic } \\
\text { design and architecture }\end{array}$ & & 0.686 & \\
\hline I prefer to visit Islamic holy places & & 0.573 & \\
\hline $\begin{array}{l}\text { I like to visit Islamic historical places in } \\
\text { other countries }\end{array}$ & & 0.637 & \\
\hline $\begin{array}{l}\text { I prefer to travel to Islamic countries for } \\
\text { entertainment }\end{array}$ & & 0.814 & \\
\hline $\begin{array}{l}\text { I prefer to travel with my family to } \\
\text { Islamic countries }\end{array}$ & & 0.785 & \\
\hline $\begin{array}{l}\text { I prefer to conduct my business in } \\
\text { Islamic countries }\end{array}$ & & 0.770 & \\
\hline $\begin{array}{l}\text { I prefer to experience nature in } \\
\text { Islamic countries }\end{array}$ & & 0.769 & \\
\hline
\end{tabular}


Appendix 1: (continued)

\begin{tabular}{|c|c|c|c|}
\hline Factors & Source & $\begin{array}{l}\text { Factor } \\
\text { loading }\end{array}$ & $\begin{array}{c}\text { Cronbach's } \\
\text { Alpha } \alpha\end{array}$ \\
\hline $\begin{array}{l}\text { I prefer to choose Islamic countries for } \\
\text { medical treatment }\end{array}$ & & 0.664 & \\
\hline Hedonic Avoidance Travel Preferences & & & 0.819 \\
\hline $\begin{array}{l}\text { I do not like to gamble during my } \\
\text { holiday }\end{array}$ & & 0.804 & \\
\hline $\begin{array}{l}\text { I do not plan to go to bars and or } \\
\text { night clubs }\end{array}$ & & 0.779 & \\
\hline $\begin{array}{l}\text { I do not like to have sex with strangers } \\
\text { during my travel }\end{array}$ & & 0.817 & \\
\hline Islamic Beliefs & & & 0.809 \\
\hline $\begin{array}{l}\text { I believe that Prophet Muhammad } \\
\text { instructs me on good conduct }\end{array}$ & & 0.507 & \\
\hline $\begin{array}{l}\text { I believe that the supplication }(D u a) \\
\text { helps me in my life }\end{array}$ & & 0.630 & \\
\hline $\begin{array}{l}\text { I am sensitive to my religious needs } \\
\text { while travelling }\end{array}$ & & 0.797 & \\
\hline $\begin{array}{l}\text { I believe that hijab is obligatory for all } \\
\text { women }\end{array}$ & & 0.827 & \\
\hline In my personal life, religion is important & & 0.645 & \\
\hline I believe in Judgment Day (Qiyamat) & & 0.523 & \\
\hline I believe in Prophet Muhammad & & 0.697 & \\
\hline Islam leads me to a better life & Mokhlis, 2009 & 0.656 & \\
\hline I believe that God helps me & Zamani- & 0.891 & \\
\hline I am a religious person & Farahani \& & 0.724 & \\
\hline I believe in Allah & Musa, 2012 & 0.645 & \\
\hline Islamic Practices & & & 0.897 \\
\hline $\begin{array}{l}\text { I regularly contribute to charity } \\
\text { (sadaqah) }\end{array}$ & & 0.630 & \\
\hline $\begin{array}{l}\text { I annually perform the obligation of } \\
\text { zakat }\end{array}$ & & 0.676 & \\
\hline I always perform my prayers on time & & 0.942 & \\
\hline I fast the whole month of Ramadan & & 0.808 & \\
\hline Performing hajj is my priority & & 0.898 & \\
\hline I perform my daily prayers & & 0.882 & \\
\hline I read the Quran regularly & & 0.943 & \\
\hline
\end{tabular}

